\title{
Sodium: A Wolf in Sheep's Clothing
}

\author{
Hans Oberleithner ${ }^{a}$ Hugh E. de Wardener ${ }^{b}$ \\ ${ }^{\mathrm{a}}$ Institute of Physiology II, Medical Faculty, University Münster, Münster, Germany; ${ }^{\mathrm{b}}$ Imperial College, London, UK
}

\section{Key Words}

Atomic force microscopy - Endothelial stiffness •

Plasma potassium $\cdot$ Aldosterone $\cdot$ Spironolactone however, when the concentration of plasma sodium or potassium changes towards and beyond the upper limits of the normal range.

\begin{abstract}
High blood pressure is the main cause of disease-related morbidity and mortality worldwide. It is virtually absent in populations that consume natural foods low in sodium. In other countries, however, where the individual intake of sodium is at least 10 times greater, the prevalence of arterial hypertension is about $40 \%$. Vascular endothelium plays a central role in blood pressure regulation. In addition to the kidney, the vasculature is a major target for aldosterone where it controls nonexcitable sodium channels in the endothelium. High sodium channel expression/activity downregulates the release of nitric oxide (NO), and thus determines endothelial function. Mechanical cell stiffness is therefore the means whereby high sodium channel activity reduces $\mathrm{NO}$ release. We have found that small changes of plasma sodium, but only above $139 \mathrm{~mm}$, and potassium above $4 \mathrm{~mm}$ regulate the stiffness of the submembrane actin web and thus control the shear stress-dependent activity of endothelial NO synthase, which lies directly beneath the cell membrane. Plasma sodium above $139 \mathrm{~mm}$ stiffens the actin web of the endothelial cell, and plasma potassium greater than $4 \mathrm{~mm}$ does the opposite. In conclusion, vascular endothelial cells are highly sensitive to changes in extracellular sodium and potassium but only within and above the normal range. This sensitivity may serve as a physiological feedback mechanism to regulate local blood flow. It becomes pathogenic,
\end{abstract}

In cellular physiology, stiffness is the force necessary to compress a cell for a certain distance (piconewtons per nanometer). In life, force is applied to most tissues, particularly to vascular endothelium. Hemodynamic forces, generated by the heart's contraction, give rise to shear stress at the endothelial surface. It is inevitable, therefore, that the apical cell surface undergoes pulsatile reversible deformation. It is this mechanical stimulus which triggers the activity of endothelial nitric oxide synthase (eNOS) and the release of nitric oxide (NO) [1]. The NO diffuses to the adjacent vascular smooth muscle cells which relax leading to vasodilation. This regulatory mechanism distributes the blood in the organism according to its metabolic demands. Shear stress also causes a stiff (less deformable) cell to release less NO. Endothelial mechanical stiffness, therefore, is a key function in the control of local blood supply and presumably, arterial blood pressure.

\section{Sodium}

For more than three million years, primitive man consumed less than $1 \mathrm{~g}$ per day of sodium chloride [2]. About 8,000 years ago, with the advent of agriculture and farm-

\section{KARGER \\ Fax +41 613061234 E-Mail karger@karger.ch} www.karger.com

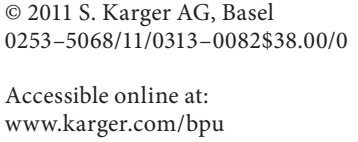

Hans Oberleithner, MD

Institut für Physiologie II

Robert-Koch-Strasse 27b

DE-48149 Münster (Germany)

Tel. +49 251835 5540, Fax +49251835 5331, E-Mail oberlei@ uni-muenster.de 
Table 1. Extracellular sodium concentration and endothelial cell stiffness in vitro

\begin{tabular}{lrccccc}
\hline Plasma sodium, $\mathrm{mM}$ & 137 & 139 & 141 & 143 & 145 \\
Increase in endothelial stiffness, \% & 0 & $+3 \pm 1.3$ & $+6 \pm 1.8$ & $+15 \pm 2.4$ & $+25 \pm 2.8$ & $+34 \pm 3.6$ \\
\hline
\end{tabular}

Reference value is a sodium concentration of $137 \mathrm{mM}$. Values ( \pm SEM) taken from Bussemaker et al. [20] and Fels et al. [21].

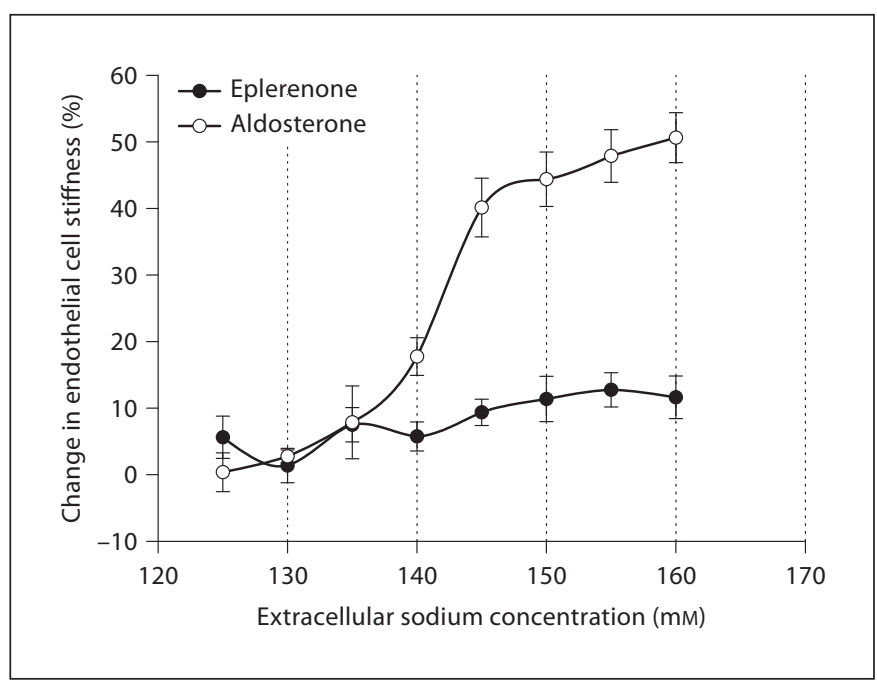

Fig. 1. Changes in endothelial cell stiffness in response to increasing sodium concentration. From Oberleithner et al. [8], with modifications.

ing, sodium chloride consumption increased to about $10 \mathrm{~g}$ per day. The main reason was to preserve foods such as bread and meat. Salt became precious because it allowed food to be stored for prolonged periods [3]. As life expectation is now close to 80 years, the harmful effects of high salt diets have become increasingly apparent. Hypertension, stroke, coronary heart disease and renal fibrosis are related to a high sodium intake [4]. Although the deleterious effects of a high sodium intake are obvious, the underlying mechanisms are still unclear. A high sodium intake causes fibrosis and inflammatory processes in the kidney and heart [5]. When dietary salt intake temporarily exceeds renal excretory capacity, the retained amount of sodium, stored in the space between cells, is increased, bound to extracellular organic material [6]. When sodium intake is raised in normal subjects and patients with hypertension, plasma sodium concentration increases by 1-4 mM [7]. It has therefore been postulated that changes in plasma sodium, per se, may influ- ence blood pressure. Accordingly, the effect of such small changes in sodium concentration on endothelial function has been studied. It has been found that when extracellular sodium is raised, endothelial cells stiffen within minutes [8]. It is remarkable, however, that in striking contrast these cells are insensitive to sodium concentrations below $139 \mathrm{mM}$. Above this concentration, however, they are highly sensitive (fig. 1; table 1). This response of the endothelium to these changes in sodium concentration is strongly dependent on aldosterone. Inhibition of the cytosolic mineralocorticoid receptors by spironolactone (or eplerenone) prevents a rise in plasma sodium stiffening the endothelium, as does inhibition of the epithelial sodium channel (ENaC; present in the apical plasma membrane of endothelia) by amiloride [8]. These in vitro experiments may explain the protective action of these two pharmaceuticals on the cardiovascular system $[9,10]$. The data strongly support the view that blood vessels and the heart, in addition to their susceptibility to the concentration of sodium, are also primary targets for diuretics, independent of their action on the kidney.

\section{Potassium}

In addition to the intake of sodium, the onset of hypertension is also controlled by the intake of potassium. Processed food products, in contrast to natural food, are rich in sodium and poor in potassium. It is generally agreed that low sodium high potassium diets, which have the least harmful effect on the cardiovascular system [11], may also have a beneficial effect on vigor and emotions such as depression and tension [12]. Potassium deficiency is difficult to detect for $98 \%$ of body potassium is intracellular. Plasma potassium, however, is controlled within narrow limits and is a sensitive indicator of a disturbance in potassium homeostasis. The effect of extracellular potassium on cultured vascular endothelial cells was therefore studied (table 2). It was found that extracellular potassium concentrations above $5 \mathrm{~mm}$ enlarge and soften endothelial cells [13]. In kidney disease, plasma potassi- 
Table 2. Extracellular potassium concentration and endothelial cell stiffness in vitro

\begin{tabular}{|c|c|c|c|c|c|c|}
\hline Plasma potassium, $\mathrm{mM}$ & 4 & 4.5 & 5.0 & 5.5 & 6.0 & 6.5 \\
\hline Decrease in endothelial stiffness, $\%$ & 0 & $-2 \pm 1.3$ & $-4 \pm 1.8$ & $-11 \pm 2.4$ & $-16 \pm 2.8$ & $-19 \pm 3.6$ \\
\hline
\end{tabular}

Reference value is a potassium concentration of $4 \mathrm{mM}$. Values ( \pm SEM) taken from Oberleithner et al. [22].

um is often raised due to acidosis and the retention of potassium. In normal subjects, during exercise, though plasma potassium concentration remains normal, there may be a rise greater than $5 \mathrm{~mm}$ in muscle [14]. A similar rise occurs in the brain during increased neuronal activity [15].

The extent of potassium-induced endothelial cell softening depends on the concentration of extracellular sodium. In 'low' sodium conditions (sodium $<140 \mathrm{mM}$ ), an increase in extracellular potassium from 4 to $6 \mathrm{~mm}$ reduces stiffness by $21 \%$. In 'high' sodium conditions (sodium $>140 \mathrm{mM}$ ), however, the decrease in stiffness induced by the same rise in potassium is only about 6\% [13]. These observed interactions between extracellular sodium and potassium have been observed in vitro under well-controlled conditions. The situation may be different in vivo, but it should be kept in mind that mechanical stiffness (i.e. cell deformability or compliance) determines NO release.

\section{Nitric Oxide}

eNOS is located close to the inner surface of the apical cell membrane, and its expression and/or activity is regulated by various factors. eNOS is stimulated by increases in intracellular $\mathrm{Ca}^{2+}$ independent of the initial stimulus, e.g. bradykinin or shear stress. There is accumulating evidence that sodium and aldosterone control eNOS activity, possibly through $\mathrm{ENaC}$-mediated sodium influx. On the other hand, inhibition of ENaC-mediated sodium influx by amiloride activates eNOS [16]. An increase in the intake of salt induces the intracellular production of asymmetrical dimethyl-L-arginine which is a competitive eNOS inhibitor [17], and increasing extracellular sodium within the physiological range downregulates eNOS expression and angiogenesis [18]. It is noticeable that (a) there is a negative correlation between mechanical stiffness and eNOS activity, (b) extracellular sodium concentration strongly determines stiffness and therefore eNOS function, and (c) extracellular potassium con- centration influences eNOS activity and stiffness only at 'low' sodium concentrations.

A question remains: Does eNOS activity depend on cell stiffness or does cell stiffness depend on eNOS activity? In other words, does the cell deformability determine eNOS activity or does NO modify the mechanical compliance of the cell? This question was recently addressed in our laboratory using an experimental procedure that allowed the simultaneous measurement of hormone-induced change in stiffness and NO release. The results clearly show that mechanical stiffness determines NO release and not vice versa [19].

\section{Outlook}

The finding that endothelial cells modify their function in response to small changes in the extracellular concentration of sodium and potassium, only within and above the normal range, could be relevant to dialysis patients. These in vitro experiments suggest that the most favorable condition for the maintenance of normal blood pressure and the prevention of cardiovascular damage is to consume a diet which tends to keep plasma sodium and plasma aldosterone in the low-normal range and plasma potassium in the high-normal range.

\section{Acknowledgement}

Work in the author's laboratory was supported by grants from the Deutsche Forschungsgemeinschaft (OB 63/17-1 and Koselleck Grant OB 63/18).

\section{Disclosure Statement}

There is no conflict of interest. 


\section{References}

1 Rizzo V, McIntosh DP, Oh P, Schnitzer JE: In situ flow activates endothelial nitric oxide synthase in luminal caveolae of endothelium with rapid caveolin dissociation and calmodulin association. J Biol Chem 1998;273: 34724-34729.

$\checkmark 2$ Meneton P, Jeunemaitre X, de Wardener HE, MacGregor GA: Links between dietary salt intake, renal salt handling, blood pressure, and cardiovascular diseases. Physiol Rev 2005;85:679-715.

$\checkmark 3$ Ritz E: Salt - friend or foe? Nephrol Dial Transplant 2006;21:2052-2056.

4 Adrogue HJ, Madias NE: Sodium and potassium in the pathogenesis of hypertension. $\mathrm{N}$ Engl J Med 2007;356:1966-1978.

$\checkmark 5$ Sanders PW: Vascular consequences of dietary salt intake. Am J Physiol Renal Physiol 2009;297:F237-F243.

-6 Titze J, Lang R, Ilies C, Schwind KH, Kirsch KA, Dietsch P, Luft FC, Hilgers KF: Osmotically inactive skin $\mathrm{Na}^{+}$storage in rats. Am J Physiol Renal Physiol 2003;285:F1108F1117.

$\checkmark 7$ de Wardener HE, He FJ, MacGregor GA: Plasma sodium and hypertension. Kidney Int 2004;66:2454-2466.

$\checkmark 8$ Oberleithner H, Riethmuller C, Schillers H, MacGregor GA, de Wardener HE, Hausberg M: Plasma sodium stiffens vascular endothelium and reduces nitric oxide release. Proc Natl Acad Sci USA 2007;104:1628116286.
-9 Pitt B, Remme W, Zannad F, Neaton J, Martinez F, Roniker B, Bittman R, Hurley S, Kleiman J, Gatlin M: Eplerenone, a selective aldosterone blocker, in patients with left ventricular dysfunction after myocardial infarction. N Engl J Med 2003;348:13091321.

10 Teiwes J, Toto RD: Epithelial sodium channel inhibition in cardiovascular disease a potential role for amiloride. Am J Hypertens 2007; 20:109-117.

11 Haddy FJ, Vanhoutte PM, Feletou M: Role of potassium in regulating blood flow and blood pressure. Am J Physiol Regul Integr Comp Physiol 2006;290:R546-R552.

12 Torres SJ, Nowson CA, Worsley A: Dietary electrolytes are related to mood. Br J Nutr 2008;100:1038-1045.

13 Oberleithner H, Callies C, Kusche-Vihrog K, Schillers H, Shahin V, Riethmuller C, MacGregor GA, de Wardener HE: Potassium softens vascular endothelium and increases nitric oxide release. Proc Natl Acad Sci USA 2009;106:2829-2834.

14 Mohr M, Nordsborg N, Nielsen JJ, Pedersen LD, Fischer C, Krustrup P, Bangsbo J: Potassium kinetics in human muscle interstitium during repeated intense exercise in relation to fatigue. Pflugers Arch 2004;448:452-456.

15 Kofuji P, Newman EA: Potassium buffering in the central nervous system. Neuroscience 2004;129:1045-1056.
16 Perez FR, Venegas F, Gonzalez M, Andres S, Vallejos C, Riquelme G, Sierralta J, Michea L: Endothelial epithelial sodium channel inhibition activates endothelial nitric oxide synthase via phosphoinositide 3-kinase/Akt in small-diameter mesenteric arteries. Hypertension 2009;53:1000-1007.

- 17 Fujiwara N, Osanai T, Kamada T, Katoh T, Takahashi K, Okumura K: Study on the relationship between plasma nitrite and nitrate level and salt sensitivity in human hypertension: modulation of nitric oxide synthesis by salt intake. Circulation 2000;101:856-861.

18 Li J, White J, Guo L, Zhao X, Wang J, Smart EJ, Li XA: Salt inactivates endothelial nitric oxide synthase in endothelial cells. J Nutr 2009; 139:447-451.

19 Fels J, Callies C, Kusche-Vihrog K, Oberleithner $\mathrm{H}$ : Nitric oxide release follows endothelial nanomechanics and not vice versa. Pflugers Arch 2010;460:915-923.

20 Bussemaker E, Hillebrand U, Hausberg M, Pavenstadt H, Oberleithner H: Pathogenesis of hypertension: interactions among sodium, potassium, and aldosterone. Am J Kidney Dis 2010;55:1111-1120.

21 Fels J, Oberleithner H, Kusche-Vihrog K: Ménage à trois: aldosterone, sodium and nitric oxide in vascular endothelium. Biochim Biophys Acta 2010;1802:1193-1202.

22 Oberleithner H, Kusche-Vihrog K, Schillers $\mathrm{H}$ : Endothelial cells as vascular salt sensors. Kidney Int 2010;77:490-494. 